\title{
Chalcogenides-based tubular micromotors in fluorescent assays
}

Victor de la Asunción-Nadal, ₹ Marta Pacheco, $¥$ Beatriz Jurado-Sánchez, $¥ \|^{\star}$ and Alberto

Escarpa‡ $\|^{*}$

‡Department of Analytical Chemistry, Physical Chemistry, and Chemical Engineering, University of Alcala, Alcala de Henares E-28871, Madrid, Spain. E-mail: beatriz.jurado@uah.es, alberto.escarpa@uah.es (Phone: +34 91 8854995)

॥Chemical Research Institute "Andrés M. del Río", University of Alcala, Alcala de Henares E-28871, Madrid, Spain.

\section{SUPPORTING FIGURE}

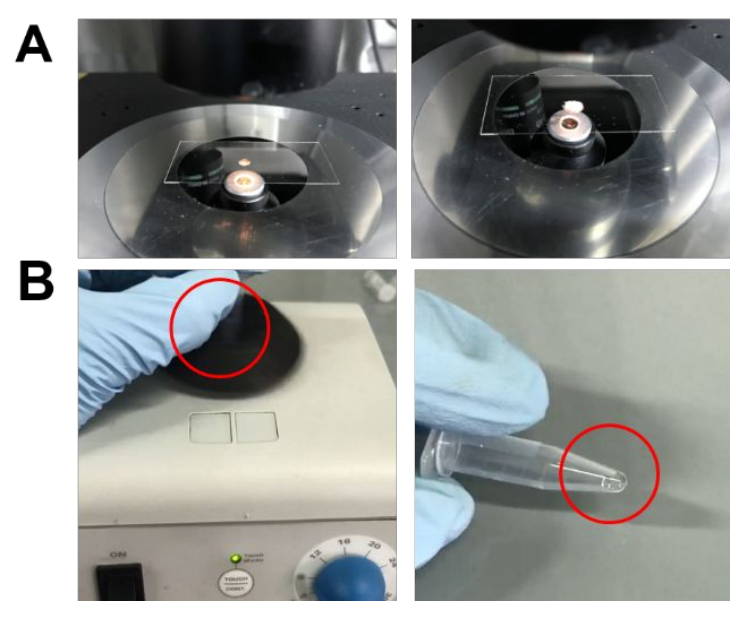

Figure S1. Experimental procedure for fluorescent assays using the $\mathrm{WS}_{2} / \mathrm{Pt}$ micromotors. (A) Direct detection on a glass slide using the modified moving micromotors. (B) Experiments under shaking. Left image shows the drop after shaking. See also Video S4. 